\title{
POLA GANTI RUGI LAHAN DALAM PEMBANGUNAN JALAN \\ BARAMBANG TAMAIRANG DESA MUARA SIKABALUAN \\ KABUPATEN KEPULAUAN MENTAWAI
}

Irwin, Ikhsan Muharma Putra, Sri Rahmadani

Program Studi Pendidikan Sosiologi STKIP PGRI Sumatera Barat

tatubeket99@gmail.com

\begin{abstract}
This research is motivated by the construction of the Barambang Tamairang road, Muara Sikabaluan Village, which was built in 2015 and approximately $6 \mathrm{~km}$. Road measurements to be made for the construction of roads on agricultural land owned by the community with an agreement will be compensated for the community's land with an agreement during a meeting at the village hall. The problem in the construction of the Barambang Tamairang road is that not all compensation has been resolved by the government. The purpose og this study is how the pattern of land compensation of the Barambang Tamairang road, Muara Sikabaluan Village, Mentawai Island Regency. The theory used in this research is the Exchange theory put forward by Peter Michael Blau. The method used in this study is a qualitative approach with a descriptive type to describe the problem under study. Retrieval of informant by purposive sampling with a total of 12 informant. There are two types of data in this study, namely primary data and secondary data. The research data was collected using observation, interview, and document study techniques. Data analysis was performed by collecting data, reducing data, presenting data and drawing conclusions with this research unit's analysis group. Based on the results of research conducted, found in the process og land compensation in the construction of the Barambang Tamairang road, Muara Sikabaluan Village, Mentawai Island Regency: (1) Deliberation of Consensus, (2) Pattern of money compensation.
\end{abstract}

\section{Keywords: Development, Compensation, Exchange.}

\section{PENDAHULUAN}

Pembangunan adalah suatu upaya perubahan yang berlandaskan pada suatu pilihan pandangan tertentu yang tidak bebas dari pengalaman (sejarah), realitas keadaan yang sedang dihadapi, serta kepentingan pihak-pihak yang membuat keputusan pembangunan. Pembangunan memiliki makna yang ganda. Pertama adalah pembangunan yang berorientasi pada pertumbuhan ekonomi yang difokuskan pada masalah kuantitatif dari produksi dari pembangunan sumber daya. Kedua adalah pembangunan yang lebih berorientasi pada perubahan dan pendistribusian barang-barang dan peningkatan hubungan sosial. Makna yang kedua lebih berorientasi pada 
pembangunan sosial yang terfokus pada pendistribusian perubahan dalam struktur dari masyarakat yang diukur dari berkurangnya diskriminasi dan eksploitasi serta meningkatkan kesempatan yang sama dan distribusi yang seimbang dari keuntungan pembangunan pada keseluruhan komponen masyarakat (Hadi, 2000:64).

Bentuk suatu pembangunan berupa pembangunan fisik dan pembangunan non fisik yang mana pembangunan ini fisik adalah pembangunan yang dilaksanakan oleh pemerintah dan oleh masyarakat. Pembangunan yang dilaksanakan oleh pemerintah pada umumnya bersifat infrastruktur atau prasarana, yaitu bangunan fisik ataupun lembaga yang mempunyai kegiatan produksi, logistik dan pemasaran barang dan jasa serta kegiatan-kegiatan yang lain di bidang ekonomi, sosial, budaya, politik dan pertahanan keamanan (Widodo, 2006). Sedangkan yang merupakan bagian dari pembangunan non fisik adalah pembangun manusia, ekonomi, pendidikan dan kesehatan (Effendi, 2002).
Desa Muara Sikabaluan merupakan salah satu desa yang ada di Kecamatan Siberut Utara Kabupaten Kepulauan Mentawai. Desa Muara Sikabaluan termasuk salah satu desa alternatif yang berada di pusat kecamatan dan menghubungkan empat desa seperti Desa Malancan, Desa Mongan Poula, Desa Sotboyak dan Desa Bojakan.

Namun demikian akses menuju salah satu desa tersebut masih memiliki kendala seperti pembangunan jalan Barambang Tamairang, yang mana kondisi awalnya masih jalan setapak yang dilewati oleh masyarakat dan masyarakat sangat susah dalam membawa hasil panen untuk dijual ke tempat penjualan yang biasa masyarakat menjual hasil panen. Untuk memasuki jalan, masyarakat harus berjalan kaki dengan beberapa rintangan seperti terjatuh karena licin, apalagi pada saat hujan terkadang yang masyarakat bawak untuk ke perkebunan masyarakat seperti makanan jatuh dan tidak bisa dimakan lagi oleh masyarakat terkadang dijemput kembali ke rumah untuk bekal masyarakat. Pada 
bulan Januari 2015 Pemerintah

Kabupaten Kepulauan Mentawai

memiliki program pembangunan

jalan Barambang Tamairang.

Pembangunan jalan tersebut dibangun pada tahun 2015 dan kurang lebih ada sekitar $6 \mathrm{~km}$ dari Dusun Pokai ke Desa Mongan Poula. Lahan tersebut adalah lahan masyarakat di mana masyarakat Pokai dan Mongan Poula, tempat mereka mencari kehidupan (ladang) di mana lahan masyarakat terdapat beberapa tanaman yaitu kelapa, cokelat, pisang, dan sagu. Padahal pembangunan jalan tersebut merupakan jalan utama menujuh sekolah SMP, kantor cabang, Puskesmas dan menghubungkan beberapa perkampungan lainnya seperti Desa Sotboyak, Desa Bojakan dan Desa Malancan.

Pada pembangunan jalan tersebut masyarakat mengadakan musyawarah antara masyarakat Dusun Pokai dengan masyarakat Mongan Poula dengan kepala proyek yang membangun jalan tersebut dan dihadiri oleh kepala Desa Muara Sikabaluan yang dilaksanakan di balai Desa tepatnya pada bulan
Januari 2015. Hasil dari musyawarah tersebut masyarakat bersedia membebaskan tanah yang terkena dalam pembangunan jalan tersebut, tetapi masyarakat meminta ganti rugi dalam bentuk tanaman yang terkena dalam pembangunan jalan tersebut. Masyarakat meminta tiga bentuk ganti rugi yaitu ganti rugi dalam bentuk uang, ganti rugi dalam bentuk bibit tanaman, serta jaminan kesehatan selama masyarakat bekerja dalam proyek tersebut dengan membuat surat perjanjian dengan kesepakatan bersama.

Setelah adanya musyawarah, masyarakat melakukan pengukuran yang akan dibuat untuk pembangunan jalan pada bulan Februari 2015, yang dihadiri oleh Kepala Desa Muara Sikabaluan, Kepala Desa Mongan Poula dan masyarakat yang terdampak. Kemudian pembangunan jalan tersebut mulai dikerjakan pada bulan februari 2015. Setelah dua bulan berjalan pembangunan proyek tersebut, Baharudin selaku ketua pelaksana pembangunan jalan.

Memberikan ganti rugi dalam bentuk bibit tanaman (garu), 
langsung dengan pihak yang bersangkutan yang meminta ganti rugi dalam bentuk tanaman. Pembangunan masih berjalan sampai dua bulan kemudian dan masyarakat masih menunggu ganti rugi lainnya. Setelah masyarakat menunggu tidak ada kabar tentang ganti rugi maka masyarakat menuntut tanaman yang terkena dalam pembangunan jalan tersebut. Karena tidak adanya informasi kelanjutan ganti rugi maka pada bulan Juni 2015, masyarakat menghentikan pembangunan dengan tidak boleh bekerja sampai ganti rugi itu terselesaikan.

Pembangunan khususnya infrastruktur jalan raya Dusun Pokai dengan Desa Mongan Poula (Barambang Tamairang) bermasalah, yang mana dalam pembangunan tersebut ada pelebaran jalan sehingga tanaman dan lahan masyarakat dipinggir jalan masuk kawasan pelebaran.

Berdasarkan permasalahan diatas, sehingga peneliti mengkaji tentang Pola Ganti Rugi didesa Muara Sikabaluan maka dari peneliti mendeskripsikan pola ganti rugi lahan dalam pembangunan jalan btambang tamairang Desa Muara Sikabaluan Kabupaten Kepulauan Mentawai.

\section{METODE PENELITIAN}

Penelitian ini menggunakan penelitian kualitatif dengan tipe deskriptif. Pendekatan ini menggunakan pendekatan kualitatif yaitu suatu pendekatan yang bermaksud untuk memahami tentang apa yang dialami oleh subjek penelitian, data yang diperoleh dapat berbentuk kata-kata, gambaran holistik dan rumit (Moleong, 2007). Penelitian ini memilih pendekatan kualitatif dianggap mampu menggambarkan suatu kenyataan atau fenomena yang ada dan menjelaskan masalah yang diteliti secara mendalam tentang pola ganti rugi lahan dalam pembangunan jalan Brambang Tamairang Desa Sikabaluan Kabupaten Kepulauan Mentawai. Tipe penelitian deskriptif yaitu penelitian yang dimaksudkan untuk memperoleh gambaran mendalam, sistematis, faktual, dan akurat mengenai fakta serta 
hubungan antara fenomena yang diselidiki (Nasir, 2003).

Penelitian ini mengunakan pendekatan kualitatif dengan tipe deskriptif adalah untuk mengetahui, mengungkapkan, mendeskripsikan dan untuk mengetahui situasi secara mendalam mengenai pola ganti rugi lahan dalam pembangunan jalan barambang tamairang Desa Sikabaluan Kabupaten Kepulauan Mentawai.

\section{Penelitian dilaksanakan}

didesa Sikabaluan karena didesa tersebut terjadi permasalahan ganti rugi lahan. Dalam penelitian ini penulis menggunakan teknik purposive sampling. Dalam penelitian ini menggunakan teknik purposive sampling karena mengetahui tentang pembangunan jalan Barambang Tamairang Desa Sikabaluan yang terjadi kendala karena lahan milik masyarakat tidak mendapatkan ganti rugi sesuai dengan kesepakatan. Hal ini informan juga memiliki kriteriakriteria dalam mendapatkan informasi yang valid. Dengan jumlah informan sebanyak 12 orang yang terkait dan mengetahui pola ganti rugi lahan dalam pembangunan jalan Barambang Tamairang Kabupaten Kepulauan Mentawai tersebut.

Menurut buku (Sugiyono, 2013:145) dapat dibedakan dalam dua bentuk yaitu participant observation dan non-participant observation. Dalam penelitian ini peneliti menggunakan nonparticipant observation yaitu suatu bentuk observasi yang dilakukan dengan melihat dan menggambarkan semua aktivitas-aktivitas di lapangan yang terjadi. Maksudnya dimana peneliti tidak ikut didalam kehidupan orang yang akan diobservasi, dan secara terpisah berkedudukan selaku pengamat. Dalam penelitian ini melakukan observasi didesa Muara Sikabaluan pada tanggal 14 Januari 2020. Observasi pada tempat diketahui oleh subjek yang akan diteliti. Adapun yang di observasi adalah melihat kondisi pembangunan pada saat ini, kondisi jalan nya sudah ditutupi oleh rumput sehingga hanya sebagian kecil saja yang jalan yang bisa dilewati oleh masyarakat seperti jalan setapak. 
Pembangunan jalan

Barambang Tamairang yang berada di Desa Muara Sikabaluan Kabupaten Kepulauan Mentawai. Di mana peneliti melakukan beberapa tahap dalam untuk observasi. Pertama peneliti melakukan pemantauan jalan dari mulainya di buka jalan sampai terakhir jalan itu dibangun dengan berjalan kaki karena badan jalan sudah ditutupi oleh semak-semak.

Wawancara mendalam ini merupakan suatu cara pengumpulan data atau informasi dengan langsung bertatap muka dengan informan, dengan maksud mendapatkan gambaran lengkap dengan topik yang diteliti. Wawancara mendalam dilakukan secara intensif dan berulang-ulang(Yusuf, 2005).

Penelitian ini yang didalamnya melibatkan wawancara dengan pihak-pihak yang terkait yaitu Kepala Desa Muara Sekabaluan, kepala proyek dan masyarakat yang terkena dampak pembangunan jalan Barambang Tamairang secara tatap muka. Sebelum melakukan wawancara terhadap informan yang ditentukan, terlebih dahulu peneliti membuat pedoman wawancara yang berisikan pertanyaan-pertanyaan yang berkenaan dengan pembangunan jalan Barambang Tamairang. Wawancara dilakukan bersifat tidak terstruktur karena peneliti bebas mengacak pertanyaan yang sudah disiapkan.

\section{HASIL DAN PEMBAHASAN}

1. Proses Ganti Rugi Lahan Dalam Pembangunan Jalan Barambang Tamairang Desa Muara Sikabluan Kabupaten Kepulauan Mentawai.

Berdasarkan hasil penelitian mengenai proses ganti kerugian dalam pembangunan Jalan Barambang Tamairang Desa Muara Sikabaluan Kabupaten Kepulauan Mentawai mengundang masyarakat ke balai Desa untuk mengadakan musyawarah kepada seluruh masyarakat Desa Muara Sikabaluan, tepatnya pada bulan Januari 2015 guna untuk mendengarkan perencanaan pelaksanaan pembangunan jalan Barambang Tamairang. Dalam pertemuan ini Kepala Desa menjelaskan bahwa, diadakannya pembangunan jalan Barambang Tamairang 
membutuhkan lokasi tanah sekitar 6 km. Kemudian selanjutnya Kepala Desa menjelaskan lagi bahwa dalam pembangunan jalan tersebut bermanfaat untuk mempermudah akses jalan masyarakat dalam melakukan aktivitas.

\subsection{Musyawarah Mufakat}

Proses musyawarah tersebut Kepala Desa telah membuat proposal yang di mana lokasi pembangunan jalan Barambang Tamairang yang telah diajukan kepada Kabupaten Kepulauan Mentawai, dalam pemantauan lokasi ini tanah yang diperlukan untuk pembangunan jalan Barambang Tamairang sekitar $6 \mathrm{~km}$ yang mana tanah yang $6 \mathrm{~km}$ tersebut terkena lahan masyarakat. musyawarah mufakat dilakukan antara masyarakat yang terkena dampak pembangunan dengan pemerintah beserta kepala desa dan pihak proyek. Dalam proses ini Kepala Desa meminta kepada pemerintah terhadap tanah masyarakat yang terkena dampak proyek pembangunan, dalam musyawarah mufakat ini pemerintah beserta pihak proyek dan kepala desa mencarikan solusi untuk pembebasan lahan miliki masyarakat. solusi yang didapatkan dalam musyawarah mufakat ini yaitu bentuk ganti rugi uang, tanaman, dan jaminan kesehatan selama masyarakat bekerja dalam proyek pembangunan jalan tersebut.

Hasil dari musyawarah mufakat mendapatkan tiga point yang telah disepakati bersama masyarakat dengan pemerintah dan juga pihak proyek.

1. Ganti rugi uang

Dalam satu bibit tanaman masyarakat yang terkena pembangunan dihargai seratus ribu dalam satu batang

2. Ganti rugi bibit tanaman Dalam ganti rugi tanaman jumlah yang didapatkan oleh masyarakat sebanyak dua puluh bibit untuk satu orang

3. Jaminan kesehatan

Dalam poin ini masyarakat yang bekerja dalam proyek pembangunan jalan mendapatkan jaminan kesehatan

\subsection{Keputusan Penyerahan Tanah}


Berdasarkan dalam proses bentuk dan ganti rugi yang sudah disepakati oleh masyarakat yang dilakukan dengan musyawarah antara pemerintah dengan masyarakat pemilik tanah, tempatnya dilakukan di balai Desa Muara Sikabaluan tepatnya pada tanggal 15 januari 2015. Kemudian Kepala Desa yang bernama Samuel Sabebegen memutuskan penyerahan tanah dengan panjang sekitar $6 \mathrm{~km}$, memutuskan secara resmi dengan membuat surat perjanjian penyerahan tanah kepada pemilik tanah dan saksi-saksi yang bernama Jonas Saurei, Jonatan, Meiyanto, dan Sudirman. Pembagian tanah yang didapatkan oleh masyarakat dengan keputusan kepala desa, untuk membuka lahan pertanian kepala suku akan memberikan se bidang tanah kepada masyarakat yang ingin bercocok tanam dengan kesepakatan masyarakat tersebut hanya memiliki hak pakai tidak hak milik. Tujuan perjanjian tersebut adalah agar tidak terjadi tuntutan apapun disuatu saat nanti. Apabila dikemudian hari ada yang menggugat surat tersebut maka pihak pemilik tanah bersedia menanggung segala akibat dan bersedia dituntut sesuai dengan hukum yang berlaku di Negara Republik Indonesia. Bentuk perjanjian ini dibuat secara tertulis dengan pakai materai 6000 .

\section{Pola Ganti Rugi Tanaman}

Pola ganti rugi tanaman ini melalui proses musyawarah yang dilakukan di balai Desa, dalam musyawarah mufakat masyarakat mengetahui adanya pembangunan jalan yang memberikan manfaat bagi mereka untuk akses ke desa lain dalam hal menjual hasil pertanian, pembangunan jalan Barambang Tamairang ini dalam pembebasan lahan mengenai lahan yang dimiliki oleh masyarakat. Proses musyawarah ini mendapatkan dukungan dari pihak masyarakat atas pembangunan jalan tersebut, yang membuat masyarakat mengambil keputusan dan kesepakatan dalam pembebasan tanah yang terkena dari pembangunan jalan ini. Pembebasan lahan petani milik masyarakat yang terkena lahannya oleh pembangunan jalan mendapatkan kesepakatan ganti rugi yang diterima oleh masyarakat 
yang tanahnya terkena dampak pembangunan jalan tersebut.

Kesepakatan dari pola musyawarah ini yaitu adanya ganti rugi tanaman yang akan diterima oleh masyarakat, pergantian lahan dengan tanaman ini merupakan permintaan masyarakat dengan cara menghitung jumlah tanaman dilahan mereka yang terkena pembangunan jalan. Setiap batang tanaman yang terkena pembangunan jalan Barambang Tamairang dihargai seratus ribu dalam satu batang yang tanamannya sudah pernah berbuah. Dalam hal ini masyarakat menyetujui ganti rugi tanaman dengan harga seratus ribu karena masyarakat menilai pembangunan jalan ini akan bermanfaat bagi masyarakat yang akan membantu mempermudah akses jalan menuju desa lainnya untuk menjual hasil tanaman dengan jarak tempuh yang relatif singkat. Lahan masyarakat yang terkena dampak pembangunan jalan ini memberikan informasi berapa jumlah tanaman masyarakat yang terkena, hal ini akan memudahkan proses ganti rugi sesuai dengan ke inginan masyarakat itu sendiri seperti ganti rugi berupa uang dan ganti rugi berupa bibit tanaman, ganti rugi diberikan oleh pihak proyek yang mana pihak proyek hanya mengantarkan bibit tanaman sampai ke desa.

\section{Pola Ganti Rugi Uang}

Pola ganti rugi uang ini sesuai dengan kesepakatan sebelumnya dalam musyawarah yang dilaksanakan di balai desa yang mendapatkan kesepakatan atas penyerahan tanah yang terkena pembangunan jalan berupa uang, dalam kesepakatan ini pihak masyarakat tidak mau menyerahkan tanahnya jika tidak adanya ganti rugi, pihak pemerintah dalam musyawarah mendapatkan langsung kesepakatan kepada masyarakat dengan mengganti rugi dengan uang, melalui musyawarah tersebut kesepakatan yang dimintai oleh masyarakat yaitu jumlah bibit mereka yang terkena oleh pembangunan jalan dihitung jumlahnya dan satu tanaman akan digantikan dengan uang seratus ribu rupiah dengan jenis tanaman yang diganti yaitu tanaman cengkeh dan kelapa.

Tanaman cengkeh dan kelapa yang diganti rugi berupa uang ini 
juga harus tanaman yang telah menghasilkan, jika tanaman yang masih bibit tidak termasuk dalam hitungan. Pihak pemerintah juga telah menyekapakati kesepakatan mengganti jumlah tanaman masyarakat yang telah menghasilkan dilahan yang terkena pembangunan jalan dengan uang.

Dalam analisis karya ilmiah ini teori yang digunakan dalam adalah teori Pertukaran Menurut Peter Michael Blau yaitu Pertukaran merupakan mengatur kebanyakan perilaku manusia dan melandasi hubungan antar individu maupun kelompok yang terjadi mulai dari pertukaran antar pribadi ke struktur sosial hingga ke perubahan sosial. Blau melihat ada empat langkah proses pertukaran yang terjadi yaitu pertukaran atau transaksi antar individu, meningkatkan ke diferensiasi status dan kekuasaan, mengarah ke legitimasi serta pengorganisasian, dan menyebarkan bibit oposisi serta perubahan(Upe, 2010:189).

Seperti yang sudah dibahas mengenai pendekatan teoritis, teori yang digunakan yaitu teori
Pertukaran dapat dipaparkan bahwa teori ini menyangkut ke dalam masalah yang diteliti oleh peneliti mengenai pola ganti rugi lahan dalam pembangunan jalan Barambang Tamairang Desa Sikabaluan Keabupaten Kepulauan Mentawai, dapat dijelaskan karena di dalam teori ini, ada konsep pertukaran atau transaksi, meningkatkan diferensiasi status dan kekuasaan, mengarah ke legitimasi serta pengorganisasian dan menyebarkan bibit oposisi serta perubahan. Kaitan dengan teori ini, peneliti melihat didalam pembangunan ada nya suatu transaksi. Transaksi tersebut bahwa didalam pembangunan jalan ini, adanya transaksi yang dilakukan antara pihak pemerintah dengan masyarakat yang mempunyai tanah. Sedangkan diferensiasi status dan kekuasaan adalah pengelompokan masyarakat berdasarkan ciri-ciri tertentu seperti adanya kekuasaan dan mengelompokkan masyarakat dalam pembangunan. Sedangkan legitimasi serta pengorganisasian adalah proses di mana sebuah organisasi digunakan untuk 
mengatasi harapan masyarakat seperti adanya harapan masyarakat dan mempermudah masyarakat didalam kehidupan pada sebuah pembangunan.

\section{KESIMPULAN}

Berdasarkan hasil penelitian dapat disimpulkan ada tiga, (1) Tujuan dari pembangunan jalan Barambang Tamairang ini untuk memperlancar semua aktivitas masyarakat dan menghubungkan beberapa desa dalam pembangunan jalan Barambang Tamairang sedangkan masalah dalam pembangunan jalan Barambang Tamairang yaitu proses ganti rugi yang belum terselesaikan (2) Pola ganti rugi lahan dalam pembangunan jalan Barambang Tamairang, dilaksanakan dengan tahapan: a). sosialisasi ganti rugi, b). Kepala Desa mengadakan perkumpulan tentang rencana pembangunan jalan, c). musyawarah dilakukan untuk mendapatkan persetujuan dari para pemilik tanah mengenai bentuk dan besarnya ganti rugi, d). bentuk ganti rugi yang diberikan pemerintah ada tiga, yaitu ganti rugi uang, tanaman, dan jaminan kesehatan selama masyarakat bekerja, e). penetapan keputusan tanah dilakukan secara resmi dengan membuat surat perjanjian penyerahan tanah, (3) Ada dua pola ganti rugi yang dilaksanakan dalam pembangunan jalan Barambang Tamairang yaitu pola ganti rugi uang dan pola ganti rugi tanaman. Di mana pola ganti rugi uang belum terselesaikan sedangkan pola ganti rugi tanaman sudah diselesaikan dan sudah diserahkan kepada masyarakat yang bersangkutan.

\section{DAFTAR PUSTAKA}

Effendi, Bachiar. 2002. Pembangunan Daerah Otonom Berkeadilan. Yoyakarta: Kurnia Kalam Semesta.

Hadi, S. P. 2000. Aspek Sosial Amdal. Gaja Mada University Press.

Moleong, Lexy. J. 2007. Metodologi Penelitian Kualitatif. Bandung: PT Remaja Rosdakarya.

Nasir. 2003. Metode Penelitian. jakarta: Ghalia Indonesia.

Sugiyono. 2013. Memahami Penelitian Kualitatif. Bandung: Alfabeta.

Upe, Ambo. 2010. Tradisi Aliran Dalam Sosiologi. Jakarta: 
Rajawali Perss.

Widodo, Tri. 2006. Perencanaan

Pembangunan. Yoyakarta: UPP STIM YKPN.

Yusuf, A.Muri. 2005. Metodologi

Penelitian. Padang: UNP. 